\title{
Coastal-change and glaciological maps of Antarctica
}

\author{
Richard S. Williams, JR, \\ U.S. Geological Survey, Quisselt Campus, Woods Hole, MA 02543, U.S.A. \\ JANE G. FERRIGNO, \\ U.S. Geological Survey, 914 National Center, Reston, VA 22092, U.S.A. \\ Charles Swithinbank, \\ Scoll Polar Research Institule, Lensfield Road, Cambridge CB2 1ER, England \\ BAERBEL K. LucchitTA, \\ U.S. Geological Survey, 2255 North Gemini Road, Flagstaff, AZ 86001, U.S.A. \\ BARbara A. SEekins \\ U.S. Geological Survey, Quissell Campus, Woods Hole, MA 02543, U.S.A.
}

\begin{abstract}
In spite of their importance to global climate and sea level, the mass balance of the Antarctic ice sheet and the dynamics of the coast of Antarctica are largely unknown. In 1990, the U.S. Geological Survey, in cooperation with the Scott Polar Research Institute, U.K., began a long-term coastal mapping project in Antarctica that is based on analysis of Landsat images and ancillary sources. The project has five objectives: (1) to determine coastline changes that have occurred between the mid-1970s and the late 1980s/early 1990s; (2) to establish an accurate base-line series of 24 1:1000000 scale maps that define the glaciological characteristics of the coastline; (3) to determine velocities of outlet glaciers, ice streams and ice shelves; (4) to compile a comprehensive inventory of outlet glaciers and ice streams; and $(5)$ to compile a 1:5000000 scale map of Antarctica derived from the 24 maps. Analysis of images used in producing the first five of the 24 maps has shown that ice fronts, iceberg tongues and glacier tongues are the most dynamic and changeable features in the coastal regions of Antarctica. Seaward of the grounding line of outlet glaciers, ice streams and ice shelves, the floating margin is subject to frequent, large calving events and rapid flow. Although calving does occur along ice walls, the magnitude of their change on an annual to decadal basis is generally not discernible on Landsat images; therefore, ice walls can be used as relatively stable reference features for measuring other changes along the coast. Velocities of outlet glaciers, ice streams and ice shelves range from 0.1 to several kilometers per year.
\end{abstract}

\section{INTRODUCTION}

\section{Background}

Changes in the area and volume of polar ice sheets are intricately linked to changes in global climate and may severely impact on the densely populated coastal regions on Earth. Melting of the West Antarctic part of the Antarctic ice sheet alone could cause a sea-level rise of as much as $6 \mathrm{~m}$. The potential sea-level rise for the entire Antarctic ice sheet is estimated to be $73 \mathrm{~m}$ (Williams and Hall, 1993). In spite of its importance, the mass balance (the net volumetric gain or loss) of the Antarctic ice sheet is poorly known; it is not known whether the ice sheet is growing or shrinking (U.S. Department of Energy, 1985).
As a result, measurement of changes in the Antarctic ice sheet was given a very high priority in recommendations by the United States Polar Research Board (1986), the Scientific Committee on Antarctic Research (SCAR) (Budd and others, 1989) and the National Science Foundation's Division (elevated to Office status on 13 January 1993) of Polar Programs (1990). A set of mostly mid-1970s Landsat images of Antarctica Swithinbank, 1988) gave the impetus for preparing a series of 24 1: 1000000 scale U.S. Geological Survey Miscellaneous Investigations Series maps ("I-maps") of the coastal regions of Antarctica (Fig. 1); the series was later modified to include Landsat 4 and 5 Multispectral Scanner (MSS) and Thematic Mapper (TM) images to compare changes over a 15-20 year time interval. 


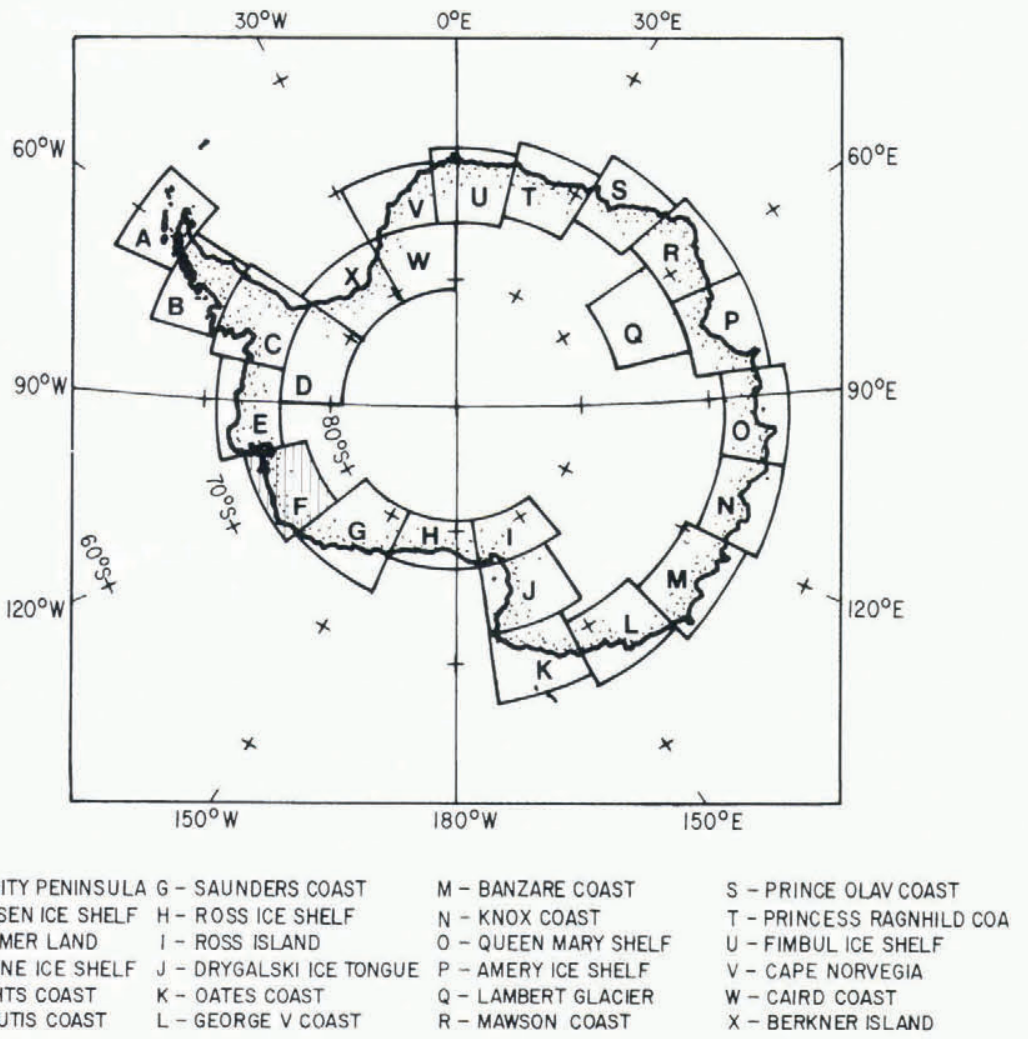

Fig. 1. Index map of Antarctica showing the locations and names of the planned 24 1:1000000 scale coastal-change and glaciological maps of Antarctica. The Bakutis Coast map is indicated by the letter F.

\section{Objectives}

The coastal-change and glaciological mapping project has five objectives:

1. To determine coastline changes that have occurred between the mid-1970s and the late 1980s/early 1990s.

2. To establish an accurate base-line series of $1: 1000000$ scale maps that defines, from the analysis of Landsat images, the glaciological characteristics (e.g. floating ice, grounded ice) of the coastline of Antarctica during the two time periods (mid-1970s and late 1980s/early $1990 \mathrm{~s})$.

3. To determine velocities of outlet glaciers, ice streams and ice shelves from comparison of Landsat images of the same areas taken over time.

4. To compile a comprehensive inventory of named (from published maps and Landsat images) and unnamed (from analysis of Landsat images) outlet glaciers and ice streams in Antarctica that are mappable from Landsat images or from ancillary sources (e.g. maps, gazetteers, CD-ROMs) (Swithinbank, 1980, 1985; Alberts, 1981; National Science Foundation, 1989; BAS, SPRI and WCMC, 1993).

5. To compile a 1:5000000 scale map of Antarctica derived from the 24 1:1000000 scale maps. Each 1:1000000 scale map extends to the southernmost nunatak within each map area or to the southernmost extent of Landsat images (about $81.5^{\circ} \mathrm{S}$. lat.).

\section{Sources of images}

Images used in the compilation of the coastal-change and glaciological maps of Antarctica were obtained from either the U.S. Geological Survey's EROS Data Center, Sioux Falls, SD 57198, U.S.A., or the Earth Observation Satellite (EOSAT) Corporation, 4300 Forbes Blvd, Lanham, MD 20706, U.S.A. The optimum Landsat 1, 2 and 3 MSS Williams and Ferrigno, 1988) and Landsat 4 and 5 TM images are shown in two index maps on each map sheet; the images used in the final compilation are noted in underlying tables with an asterisk. The 1:500000 scale prints of Landsat images used in the analytical phase were enlarged from three types of source material: (1) 1:3369000 scale film transparencies from the EROS Data Center, (2) 1:1000000 scale black-andwhite or false-color prints from EOSAT, and (3) 1:500000 scale black-and-white prints made from digitally enhanced images at the U.S. Geological Survey's Image Processing Facility, Flagstaff, AZ, U.S.A.

\section{Methodology}

The primary steps in the compilation of the coastalchange and glaciological maps of Antarctica are as follows:

1. Identification of optimum Landsat MSS or TM images for the two time periods (mid-1970s and late 1980 s/early 1990s) and enlargement to a nominal scale of $1: 500000$.

2. Identification and plotting of ground control points and pass points on Landsat images pass points tie 
overlapping Landsat images together in the absence of ground control) from geodetic field-survey information (e.g. field notebooks, tables, vertical and trimetrogon aerial photographs, maps) archived in the U.S. Geological Survey's SCAR Library (Reston, VA 22092, U.S.A.). Plotting of pass points on overlapping Landsat images and transfer of control points and pass points to transparent overlays to provide ties between images in areas where geodetic ground control does not yet exist.

3. Manual annotation of glaciological features by SCAR Code SCAR, 1980) or Antarctic Digital Database (ADD) Geocode (BAS, SPRI and WCMC, 1993) on 1:500000 scale transparent overlays of Landsat images for both time periods. (The ADD project provides a digitized coastline and other cartographic information on Antarctica generalized to a scale of $1: 1000000$ which is available on a CD-ROM (BAS, SPRI and WCMC, 1993). The ADD CD-ROM provides the best existing coastline information for Antarctica.

4. Manual transfer of the combined (MSS with TM) annotated overlays to 1:500000 scale oblique Mercator maps of each map sheet. TM images provide the most geometrically accurate base for combining the annotations derived from analysis of the MSS and TM images.

5. Digitization, at $1: 500000$ scale, using the U.S. Geological Survey's MAPGEN software (Evenden and Botbol, 1985) and a digitizing program called "digin", written by G.I. Evenden (unpublished), of glaciological annotations and other related information on the oblique Mercator projections by SCAR Code or ADD Geocode.

6. Transformation of digitized annotations to a 1:1000000 scale polar stereographic map base (standard parallel at $71^{\circ} \mathrm{S}$ lat.) using the U.S. Geological Survey's MAPGEN software (Evenden, 1990).

7. Addition of glacier velocities, geographic place-names, including codes for unnamed outlet glaciers and ice streams identified on Landsat images (Table 1), and modification of selected topographic (BAS, SPRI and WCMC, 1993) form lines and bathymetric contours.

8. Analysis of coastal changes, glaciological features and outlet-glacier, ice-stream and ice-shelf velocities.

\section{THE BAKUTIS COAST MAP}

Analysis of the two sets of Landsat images for the two time periods has been completed for five of the 24 maps (Fig. 1) (Eights Coast, Bakutis Coast (Swithinbank and others, in press), Saunders Coast, Ross Ice Shelf and Ross Island). The following discussion of the Bakutis Coast map is used as an example of the types of coastal-change and glaciological information that can be derived from analysis of Landsat MSS and TM images (Swithinbank and others, in press).
Table 1. Inventory of named and unnamed glaciers located within the Bakutis Coast map
Named

Beakley Glacier

Boschert Glacier

Brush Glacier

Bunner Glacier

Clausen Glacier

Dorchuk Glacier

Hamilton Ice Piedmont

Haynes Glacier

Holt Glacier

Horrall Glacier

Keys Glacier

Kohler Glacier

McClinton Glacier

Park Glacier

Parks Glacier

Pope Glacier

Roos Glacier

Simmons Glacier

Singer Glacier

Smith Glacier

Sorenson Glacier

Steuri Glacier

Thurston Glacier

Thwaites Glacier

Thwaites Glacier Tongue

Thwaites Iceberg Tongue

True Glacier

Vane Glacier

Yoder Glacier

Zuniga Glacier

Unnamed $^{3}$

AN11344W7427

AN11351W7423

AN11637W7423

AN11950W7420

AN12032W 7353

AN12420W7353

AN12431W7349

AN12500W 7349

AN12524W 7345

AN12543W7334

AN12608W7322

AN12542W7444

AN12919W7452

AN12957W7455
Geographic namel
Glaciological term²

ice stream

outlet glacier

outlet glacier

outlet glacier

outlet glacier

outlet glacier

not a true ice piedmont

ice stream

outlet glacier

outlet glacier

outlet glacier

ice stream/outlet glacier

outlet glacier

outlet glacier

outlet glacier

ice stream/outlet glacier outlet glacier

outlet glacier

outlet glacier

ice stream/outlet glacier

outlet glacier

outlet glacier

outlet glacier

ice stream

ice shelf/glacier tongue

iceberg tongue

outlet glacier

outlet glacier

outlet glacier

outlet glacier

outlet glacier

outlet glacier

ice stream

ice stream

outlet glacier

outlet glacier

outlet glacier

outlet glacier

outlet glacier

outlet glacier

outlet glacier

ice stream

ice stream

ice stream

\footnotetext{
' Comprehensive listing of glaciers and selected other relevant geographic features derived from published maps of the area encompassed by the Bakutis Coast map and included in Alberts (1981) and National Science Foundation (1989).

2 Glaciological terms defined in Armstrong and others (1973, 1977) (primary references) and in Bates and Jackson (1987) (secondary reference).

3 Geographic location code for unnamed outlet glaciers and ice streams that have been identified on Landsat images. AN1 1344 W 7427 represents Antarctica (AN), $113^{\circ} 44^{\prime} \mathrm{W}(11344 \mathrm{~W}), 74^{\circ} 27^{\prime} \mathrm{S}(7427)$.
} 


\section{Glaciological features}

The Bakutis Coast (Swithinbank and others, in press) shows two dominant glaciological features: relatively narrow fringing ice shelves Getz, Dotson and Crosson Ice Shelves) and the Thwaites Glacier system (Thwaites Glacier, Thwaites Glacier Tongue and Thwaites Iceberg Tongue). Getz Ice Shelf continues for another $150 \mathrm{~km}$ to the west into the Saunders Coast map. The Bakutis Coast map is divided into five ice-front segments by four islands (Dean, Siple, Carney and Wright) located between DeVicq Glacier and Martin Peninsula. Siple Island, Carney Island, Martin Peninsula and Bear Peninsula also contain small ice shelves separated by ice walls. Twentyseven named and 14 unnamed outlet glaciers and ice streams flow into the ice shelves or directly into the Amundsen Sea; three other named glaciers are located in interior mountain ranges (Table 1). The larger glaciers, such as Thwaites Glacier, may have a relatively coherent iceberg tongue as a detached part of the glacier tongue. All three glaciological features are prominent enough in the Thwaites Glacier system to carry three separate placenames.

\section{Coastal change}

As would be expected, the ice fronts, iceberg tongues and glacier tongues are the most dynamic and changeable features in the coastal regions of Antarctica (Table 2). Seaward of the grounding line of outlet glaciers, ice streams and ice shelves, the floating ice margin is subject to frequent and large calving events or rapid flow. Both of these situations lead to annual and decadal changes in the position of ice fronts on the order of several kilometers, even tens of kilometers in extreme cases of major calving events. Although calving does occur along ice walls, the magnitude of change on an annual to decadal basis is generally not discernible on Landsat images; therefore, ice walls can be used as relatively stable reference features against which to measure other changes along the coast; only a single observation date is given for the position of ice walls.

\section{Table 2. Glaciological features mappable on Landsat images that are presented on the coastal-change and glaciological maps of Antarctica. The corresponding SCAR Codes (SCAR, 1980) or ADD Geocodes (BAS, SPRI and WCMC, 1993) are also given}

\section{Flowlines}

Grounding line

Iceberg tongue

Ice front

Ice rise (within a $\mathrm{G}$ and/or $\mathrm{W}$ ) $^{1}$

Ice rumple (within a $\mathrm{G}$ and/or $\mathrm{W})^{1}$

Ice wall

Ridge line on ice

Rift

Rock coastline

Thin ice shelf

\footnotetext{
$\mathrm{G}$ indicates grounding line; $\mathrm{W}$ indicates ice wall.
}

An analysis of changes from Wrigley Gulf on the western part of the Bakutis Coast map to the western part of Pine Island Bay on the east (130-104 W long.), indicates the following. West and north of Dean Island, the Getz Ice Shelf advanced 3-12 km between 11 January 1973 and 25 February 1988 across a $51 \mathrm{~km}$ wide ice front. The eastern part of the tongue of DeVicq Glacier (mostly on the Saunders Coast map) receded $6 \mathrm{~km}$. West of Carney Island the Getz Ice Shelf receded 2-5 km between 22 December 1972 and 25 February 1988 and, on the east, $0-2 \mathrm{~km}$ between 23 November 1973 and 25 December 1986/24 January 1990. The $46 \mathrm{~km}$ wide ice front of Dotson Ice Shelf also receded 1-5 km between 16 January 1973 and 23 January 1990 (Fig. 2). The largest changes, however, occurred in the Thwaites Glacier Tongue and the adjacent Crosson Ice Shelf. From the southeastern end of the ice wall of Hamilton Ice Piedmont (about $110^{\circ} \mathrm{W}$ long.) to the ice wall west of Pine Island Glacier (about $104^{\circ} \mathrm{W}$ long.) is a distance of $186 \mathrm{~km}$. Along a $62 \mathrm{~km}$ wide front of Crosson Ice Shelf that includes the confluence of Smith, Pope and Vane Glaciers, the ice front receded $5-13 \mathrm{~km}$ between 27 December 1972 and 22 January 1988. The irregular $83 \mathrm{~km}$ wide terminus of Thwaites Glacier Tongue advanced about $10 \mathrm{~km}$ between 27 December 1972 and 22 January 1988; between 22 January 1988 and 9 February 1989, it advanced another $2 \mathrm{~km}$. The Thwaites Iceberg Tongue has continued to move farther west since 1989.

\section{Outlet-glacier, ice-stream, and ice-shelf velocities}

Velocities of floating glaciers (e.g. glacier tongues, ice streams, ice shelves) were determined by two methods: an interactive one in which crevasse patterns are traced visually on images (Lucchitta and others, 1993) and an auto-correlation program developed by Bindschadler and Scambos (1991) and Scambos and others (1992). Under optimum conditions, errors can be as small as $\pm 0.02 \mathrm{~km}$ $\mathrm{a}^{-1}$, but for most Landsat image pairs, where registration of features is only accurate to two or three pixels, the accuracy of velocity vectors is $\pm 0.1 \mathrm{~km} \mathrm{a}^{-1}$. The larger glacier tongues and ice shelves have well-developed rift patterns that can be used for velocity measurements. From 10 to 50 measurement points were made for each glacier tongue or ice shelf. Thwaites Glacier Tongue has an average velocity of $2.8 \mathrm{~km} \mathrm{a}$, on the basis of Landsat images acquired on 2 December 1984 (50276-14524) and 9 January 1990 (42734-14552) (Ferrigno and others, 1993). The Thwaites Iceberg Tongue moved west between the early 1970 s and the late 1980s. On the basis of Landsat images acquired on 13 January 1973 (1174-14325) and 22 January 1988 (42016-14343), the floating tongue of Smith Glacier moved at an average rate of $0.6 \mathrm{kma}^{-1}$, although the velocity decreased to $0.5 \mathrm{kma}^{-1}$ near the grounding line. The Smith Glacier tongue increased in velocity to an average of $0.7 \mathrm{~km} \mathrm{a}^{-1}$ between 19 January 1988 and 23 January 1990. Dotson Ice Shelf, into which several named Singer, McClinton, Dorchuk, Keys, Kohler, Boschert, True, Zuniga, Brush and Sorenson Glaciers) and other unnamed glaciers flow, has an average velocity of $0.4 \mathrm{~km} \mathrm{a}^{-1}$ (Lucchitta and others, 1993, 1994). 


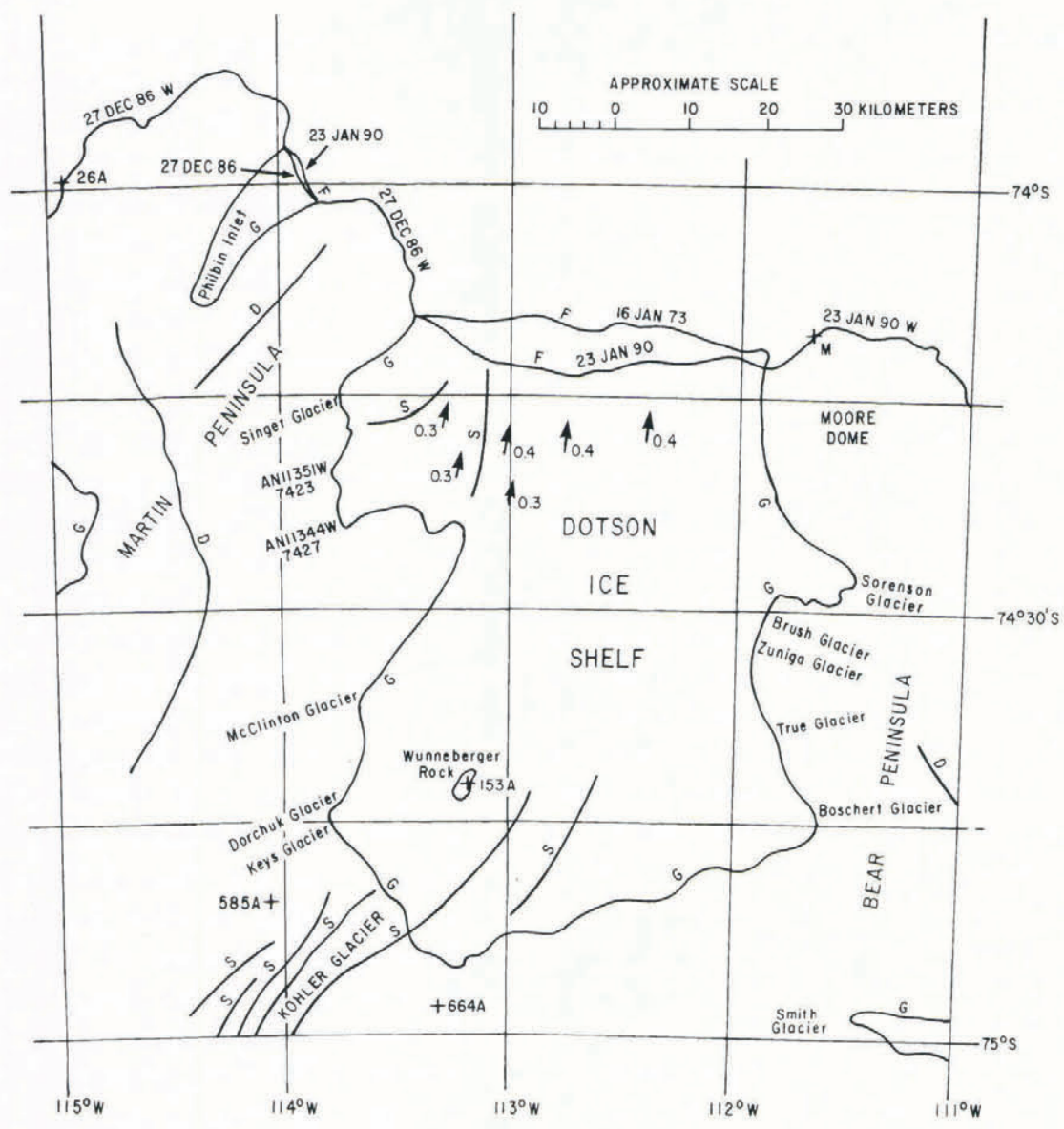

Fig. 2. The Dotson Ice Shelf and environs part of the Bakutis Coast map showing coastal change and glaciological features derived from analysis of Landsat MSS and TM images and compiled on an interim oblique Mercator map at a scale of 1: 500000 . The 1:1000000 scale map (Swithinbank and others, in press) uses color to differentiale features. On this map letters are used: $W$ (ice wall), $D$ (ridge line on ice), $S$ (flowlines), $G$ (grounding line) and $F$ (ice front) (see Table 2). Control points are shown with a "+" and identified by elevation in meters above mean sea level, if available, and type of observation: A, astronomical; M, map coordinate. Two unnamed glaciers identified on Landsal images are also shown: AN11351W7423 and AN11344W7427 (AN = Antarctica; $11351 \mathrm{~W}=113^{\circ} 51^{\prime} \mathrm{W}$ long.; $7423=74^{\circ} 23^{\prime} \mathrm{S}$ lal. $)$. The six velocity vectors were calculated from movement of features on two Landsat images, a TM image (base image) acquired on 2 January 1988 (41996-14580) and an MSS image (coregistered image) acquired on 16 . January 1973 (1177-14500). Velocity is indicated in $\mathrm{km} \mathrm{a}^{-1}$.

\section{Map revisions}

The Bakutis Coast map was compiled primarily from Landsat 4 and 5 images (supplemented with Landsat 1, 2 and 3 images to fill in gaps or to delineate coastal changes), by use of selected geodetic control from the 11 relevant sheets of the 1:250000 scale Topographic Reconnaissance Maps (with shaded relief) and three 1:500000 scale Sketch Maps (shaded relief shown, but generally without contours) published by the U.S. Geological Survey and newer control acquired with global positioning system (GPS) equipment. The only exception to the use of Landsat 4 and 5 images is in the western part of the Bakutis Coast map, where an 11 January 1973 Landsat image was used to delineate the ice front and the grounding lines of Dean Island and the inland ice sheet within the area covered by the $1: 250000$ scale Dean Island Topographic Reconnaissance map. Newer geodetic control shows that some coastal features were mislocated on earlier maps. (The Antarctic Digital Database (BAS, SPRI and WCMC, 1993) indicates that
Landsat images were used in some coastal regions to better define the coast. However, in the ADD, topographic contours and/or form lines are displaced to the south with respect to the coastline digitized from published U.S. Geological Survey maps.) Siple Island lies $20 \mathrm{~km}$ west and $25 \mathrm{~km}$ south of its originally mapped position; corresponding features on Siple Island were misplaced by as much as $33 \mathrm{~km}$. The coastline from Siple Island east to the Bear Peninsula was misplaced by 10 $15 \mathrm{~km}$ to the west of its true position. Thwaites Iceberg Tongue has advanced from its original mapped position, as would be expected. The shape is somewhat different from its 1966 outline that was based on rectification of (oblique) trimetrogon aerial photographs. Its actual length is $142 \mathrm{~km}$ vs $132 \mathrm{~km}$ in 1966, an $8 \%$ increase over the previously published map version; its greatest width is $67 \mathrm{~km}$ vs $53 \mathrm{~km}$, a $26 \%$ increase. Burke Island is also displaced about $10 \mathrm{~km}$ to the southwest on published U.S. Geological Survey maps. Its approximate dimensions are $30 \mathrm{~km}$ long and $12 \mathrm{~km}$ wide, rather than the published $22 \mathrm{~km}$ long and $5 \mathrm{~km}$ wide. Table 3 lists geographic placenames and corresponding geographic features that have 
Table 3. Glaciological and other features on the Bakutis Coast map, some of which have been revised on the basis of analysis of Landsat images. For example, Armour and Philbin Inlets are ice shelves; Bear and Duncan Peninsulas are probably islands; Dean and Numn Islands are ice rises

$\begin{array}{ll}\text { Armour Inlet } & \text { ice shelf } \\ \text { Bear Peninsula } & \text { island (?) } \\ \text { Burke Island } & \text { island } \\ \text { Carney Island } & \text { island } \\ \text { Clark Island } & \text { island } \\ \text { Crosson Ice Shelf } & \text { ice shelf } \\ \text { Dean Island } & \text { ice rise } \\ \text { Dotson Ice Shelf } & \text { ice shelf } \\ \text { Duncan Peninsula } & \text { island (?) } \\ \text { Getz Ice Shelf } & \text { ice shelf } \\ \text { Gurnon Peninsula } & \text { peninsula } \\ \text { Martin Peninsula } & \text { peninsula } \\ \text { Moore Dome } & \text { ice dome } \\ \text { Nunn Island } & \text { ice rise } \\ \text { Philbin Inlet } & \text { ice shelf } \\ \text { Scott Peninsula } & \text { peninsula } \\ \text { Siple Island } & \text { island } \\ \text { Wright Island } & \text { island }\end{array}$

been revised on the basis of analysis of Landsat MSS and TM images. For example, Armour and Philbin Inlets are ice shelves; Bear and Duncan Peninsulas are probably islands; Dean and Nunn Islands are ice rises.

\section{GLACIER INVENTORY}

Producing a sophisticated glacier inventory of Antarctica according to the requirements of the World Glacier Monitoring Service, as part of their ongoing "World Glacier Inventory" program, is impossible with the present state of glaciological knowledge about Antarctica (Swithinbank, 1980). It is, however, possible to use Landsat images, supplemented by other satellite images south of $81.5^{\circ} \mathrm{S}$ lat. (e.g. SPOT, Soyuzkarta, NOAA AVHRR), and available maps to produce a reasonably complete inventory of named and unnamed outlet glaciers and ice streams and also to define more accurately related glaciological features, such as ice domes, ice piedmonts, ice shelves, ice rises, ice rumples, glacier tongues and iceberg tongues (Tables 1 and 3 ). Satellite images also permit better distinction of islands and peninsulas, physical features that were often incorrectly identified and defined on earlier maps because of the lack of appropriate data (Table 3 ).

The comprehensive listing of 27 named glaciers and selected other named glaciological and physical features is derived from published maps of the area encompassed by the Bakutis Coast map and included in Alberts (1981) and National Science Foundation (1989). For definitions of glaciological terms, see Armstrong and others (1973, 1977 ) (primary references) and Bates and Jackson (1987) (secondary reference). The 14 unnamed glaciers and corrections to named glaciological and physical features are derived from analysis of the Landsat images.

\section{ACKNOWLEDGEMENTS}

We would like to acknowledge the outstanding support provided for the preparation of this map series by D'A. F. Lear, senior archivist of the SCAR Library, Reston, VA, which is administered by the U.S. Geological Survey's National Mapping Division. We appreciate the contributions of K.F. Mullins and C. E. Rosanova, U.S. Geological Survey (Flagstaff, AZ), who performed the velocity measurements, and M.S. Grim, U.S. Geological Survey (Reston, VA), who assisted in the identification of geodetic-control points on images. C. Swithinbank's participation in the project was made possible by the much appreciated support of J. C. Comati, chief of the Environmental Sciences Branch, U.S. Army Research, Development, and Standardization Group London, U.K.) of the U.S. Army Materiel Command. M.F. Stricker, Geologic Division, provided typing support for the numerous tables of Landsat images and geodeticcontrol points. We are indebted to E. R. Driscoll and L. D. North, U.S. Geological Survey (Woods Hole, MA) for hardware and software system support and to Stephen E. Suitt, U.S. Geological Survey (Reston, VA) for transfer of topographic data from the Antarctic Digital Database CD-ROM to a format compatible with MAGPEN software. Funding for the project was provided by the Geologic Division's Global Change and Climate History Program, a component of the U.S. Geological Survey's contribution to the multi-federal agency U.S. Global Change Research Program, the U.S. part of the International Geosphere-Biosphere Programme.

\section{REFERENCES}

Alberts, F. G., ed. 1981. Geographic names of the Autarclic. Washington, DC: U.S. Board on Geographic Names. National Science Foundation Publication NSF 81-5.

Armstrong, T., B. Roberts and C. Swithinbank. 1973. Illustrated glossary of snow and ice. Second edition. Cambridge, Scott Polar Research Institute. (Special Publication 4.)

Armstrong, T., B. Roberts and C. Swithinbank. 1977. Proposed new terms and definitions for snow and ice features. Polar Rec., 18 116). $501-502$.

Bates, R. L. and J. A. Jackson, eds. 1987. Glossary of geology. Third edition. Falls Church, VA, American Geological Institute.

Bindschadler, R.A. and T.A. Scambos. 1991. Satellite-image-derived velocity field of an Antarctic ice stream. Science, 252 5003), 242-246.

British Antarctic Survey BAS), Scott Polar Research Institute (SPRI) and World Conservation Monitoring Centre (WCMC). 1993. Antarctic digital database user's guide and reference manual. Cambridge, Scientific Committee on Antarctic Research. [This manual accompanies a CD-ROM.]

Budd. W.. A. Gordon, G. Hempel, C. Lorius and G. Weller, SCAR IGBP Steering Committee. 1989. The role of Antarclica in global change: scientific priorities for the International Geosphere-Biosphere Programme (IGBP). Cambridge, ICSU Press/SCAR.

Drewry, D.J. 1983. The surface of the Antarctic ice sheet. In Drewry, D. J., ed. Antarclica: glaciological and geophysical folio. Cambridge, Scott Polar Research Institute. Sheet 2.

Evenden, G. I. 1990. Cartographic projection procedures for the UNIX environment - a user's manual. U.S. Geol. Surv. Open-Fïle Rep. 90284. With later supplements. Cartographic projection procedures. Release 4. Interim report and Second interim report 1994.

Evenden, G. I. and J. M. Botbol. 1985. User's manual for MAPGEN 
Unix version) - a method of transforming digital cartographic data to a map. U.S. Geol. Surv. Open-File Rep. 85-706.

Ferrigno, J. G., B. K. Lucchitta, K. F. Mullins, A. L. Allison, R. J. Allen and W. G. Gould. 1993. Velocity measurements and changes in the position of Thwaites Glacier/iceberg tongue from aerial photography, Landsat images and NOAA AVHRR data. Ann. Glaciol., 17. 239244.

Lucchitta, B. K., K. F. Mullins, A. L. Allison and J. G. Ferrigno. 1993. Antarctic glacier-tongue velocities from Landsat images: first results. Ann. Glaciol., 17, 356-366.

Lucchitta, B. K., K. F. Mullins, C. E. Smith and J. G. Ferrigno. 1994, Velocities of the Smith Glacier ice tongue and Dotson Ice Shelf, Walgreen Coast, Marie Byrd Land, West Antarctica. Ann. Glaciol., 20, $101-109$

National Science Foundation. 1989. Gazetteer of the Antarctic. Fourth edition. Fairfax, VA, U.S. Board on Geographic Names. (National Science Foundation Publication NSF 8998.

National Science Foundation. 1990. A long-range science plan for the Division of Polar Programs of the National Science Foundation. Washington, DC, National Science Foundation. Divisional Advisory Committee for Polar Programs. (NSF Publication 90-48.)

Scambos, T.A., M.J. Dutkiewicz, J. C. Wilson and R. A. Bindschadler. 1992. Application of image cross-correlation to the measurement of glacier velocity using satellite image data. Remole Sensing Environ., $42(3), 177-186$.

Scientific Committec on Antarctic Research (SCAR). 1980. Standard symbols for use on maps of Antarctica. Second edition. Canberra, SCAR. Working Group on Geodesy and Cartography.

Swithinbank, C. 1980. The problem of a glacier inventory of Antarctica, International Association of Hydrological Sciences Publication 126 (Workshop at Riederalp 1978 - World Glacier Inventory), 229-236.

Swithinbank, C. 1985. A distant look at the cryosphere. Adv. Space Res., $56), 263-274$.

Swithinbank, C. 1988. Satellite image atlas of glaciers of the world. Antarctica. U.S. Geol. Surv. Prof. Pap. 1386-B, 1-138.

Swithinbank, C. W.M., R.S. Williams, Jr, J. G. Ferrigno, B. K. Lucchitta and B.A. Seekins. In press. Coastal-change and glaciological map of the Bakutis Coast, Antarctica: 1972-1990. Scale 1:1000000. U.S. Geol. Surv. Miscellaneous Investigations Series.

United States Department of Energy. 1985. Glaciers, Ice Sheets, and Sea Level: Effect of a $\mathrm{CO}_{2}$-induced Climatic Change. Report of a Workshop held in Seattle, Washington, September 13-15, 1984. Washington, DC, National Academy Press.

United States Polar Research Board. 1986. U.S. research in Antarctica in 2000 A.D. and beyond: a preliminary assessment. Washington, DC, National Academy Press.

Williams, R.S., Jr and J.G. Ferrigno. 1988. Landsat images of Antarctica. U.S. Geol. Surv. Prof. Pap. 1386-B, B139-B278.

Williams, R.S., Jr and D. K. Hall. 1993. Glaciers. In Gurney, R.J., J. L. Foster and C. L. Parkinson, eds. Allas of satellite observations related to global change. Cambridge, Cambridge University Press, $401-422$. 